\title{
$\beta$-Catenin Expression in In Situ and Infiltrative Ductal Carcinomas of the Breast
}

\section{Memenin İn Situ ve İnfiltratif Duktal Karsinomlarında $\beta$-Katenin Ekspresyonu}

\author{
Tuba KARABACAK' ${ }^{1}$, Reyhan EĞiLMEZ², Rabia BOZDOĞAN ARPACI', Ebru SERINSÖZ PFEIFFER' \\ Department of Pathology, ${ }^{1}$ Mersin University, Faculty of Medicine, MERSIN, TURKEY, ${ }^{2}$ Cumhuriyet University, Faculty of Medicine, SIVAS, TURKEY \\ This study was presented as a poster at the XVIIth National Pathology Symposium held in Gaziantep between 1-6 October 2004.
}

\begin{abstract}
Objective: Cascades that include $\beta$-catenin that has a function in adhesion and interaction with tumor suppressor genes such as APC have important roles in many neoplasms. The aim of the current study was to confirm the effect of the $\beta$-catenin pathway in breast tumor carcinogenesis and invasion.
\end{abstract}

Material and Method: Polyclonal rabbit $\beta$-catenin antibody was applied to 52 cases of infiltrative ductal carcinoma and 28 cases of ductal carcinoma in situ using the Avidin Biotin complex immune peroxidase method. The intensity and cellular localization of immunostaining were evaluated and compared.

Results: $\beta$-catenin immunoreactivity similar to that of normal epithelium was observed in $7(8.75 \%)$ cases and weak or absent $\beta$-catenin expression was noted in $45(56.25 \%)$ infiltrative ductal carcinoma cases. $\beta$-catenin expression was strong in $5(6.25 \%)$ cases of ductal carcinoma in situ but weak or absent immunostaining was observed in $23(28.75 \%)$ cases.

Membranous $\beta$-catenin immunoreactivity was observed in 18 $(22.5 \%)$ cases of infiltrative and 14 (\%17.5) cases of ductal carcinoma in situ. Cytoplasmic immunostaining or complete absence of staining was noted in $34(42.5 \%)$ cases of infiltrative and $14(17.5 \%)$ cases of ductal carcinoma in situ.

Conclusion: Similar quantitative and qualitative changes in $\beta$-catenin expression were detected in a considerable proportion of in situ and infiltrative ductal carcinomas in the current study. These findings suggest that $\beta$-catenin plays a role in the carcinogenesis of infiltrative ductal carcinoma but similar expression patterns of $\beta$-catenin in infiltrative and in situ ductal carcinomas indicates that changes in $\beta$-catenin expression occur early in carcinogenesis.

Key Words: Beta catenin, Carcinoma, Ductal, Breast, Intraductal, Noninfiltrating
ÖZ

Amaç: Adezyon fonksiyonu yanısıra APC geni gibi tümör supressor genler ile etkileşmekte olan $\beta$-katenin içeren yolakların birçok neoplazide önemli rol oynadığ saptanmıştır. Bu çalışmada $\beta$-kateninin meme tümör gelişimine ve invazyona olan etkisini saptamak hedeflenmiştir.

Gereçve Yöntem: 52 infiltratif duktal karsinom ve 28 duktal karsinoma in-situ olgusuna Avidin Biotin kompleks immün peroksidaz yöntemi ile poliklonal rabbit $\beta$-katenin antikoru uygulanmıştır. $\beta$-katenin'in boyanma yoğunluğu ve hücresel lokalizasyonu karşılaştırılmıştır.

Bulgular: Çalışmada immünohistokimyasal olarak uygulanan $\beta$-katenin ile infiltratif duktal karsinom olgularının 7'sinde (\%8.75) normal meme dokusu ile benzer yoğunlukta boyanma saptanırken, 45' inde (\%56.25) zayıf boyanma / negatiflik izlenmiştir. Duktal karsinoma in-situların 5'inde (\%6.25) kuvvetli boyanma izlenirken, 23'ünde (\%28.75) zayıf boyanma / negatiflik saptanmıştır.

İnfiltratif duktal karsinomların 18'i (\%22.5) ve duktal karsinoma in-situların 14'ünde (\%17.5) $\beta$-katenin ile membranöz boyanma izlenirken, infiltratif duktal karsinomların 34'ü (\%42.5) ve duktal karsinoma in-situların 14'ünde (\%17.5) sitoplazmik boyanma izlenmiş ya da hiç boyanma saptanmamıştır.

Sonuç: Çalışmada, infiltratif ve in-situ duktal karsinom olgularının önemli bir kısmında, $\beta$-katenin ekspresyonunda benzer kalitatif ve kantitatif değişiklikler izlenmiştir. Bulgular $\beta$-katenin’in infiltratif duktal karsinom gelişiminde de rol aldığını, ancak infiltratif ve in-situ duktal karsinom arasında ekspresyon açısından fark olmaması $\beta$-katenin'de meydana gelen değişikliğin karsinogenezin erken dönemlerinde geliştiğini düşündürmektedir.

Anahtar Sözcükler: Beta katenin, Karsinom, Duktal, Meme, İntraduktal, Non-infiltratif

Correspondence: Tuba KARABACAK

Department of Pathology, Mersin University, Faculty of Medicine, MERSIN, TURKEY

E-mail: karabacaktuba@hotmail.com Phone: +90 3243374300 


\section{INTRODUCTION}

$\beta$-catenin is one of the proteins that E-cadherin, which is an adhesion molecule, has to interact with in order to carry out its mission and it is also involved in intracellular signal transduction pathways $(1,2)$. Mutations in the regulatory region of $\beta$-catenin have been investigated notably in colon cancer, malignant melanoma, prostate carcinomas, hepatocellular carcinoma, endometrial carcinoma, ovarian tumor, and tumors such as medullablastoma and pilomatrixoma (3). $\beta$-catenin is considered to be involved in the carcinogenesis of many tumors and is also thought to be effective in the development of breast cancer (4).

The aim of the study was to compare $\beta$-catenin expression levels in ductal carcinoma in situ (DCIS) and infiltrating ductal carcinoma (IDC) of the breast and determine its role in the development of invasive tumor.

\section{MATERIAL and METHOD}

A total of 52 IDC cases diagnosed between 1999-2003 at the Mersin University Medical Faculty Department of Pathology and 28 DCIS cases diagnosed between 1995-2002 at the Dokuz Eylul University Medical Faculty Department of Pathology were identified as study groups. The Avidin Biotin Complex immunoperoxidase method with $\beta$-catenin polyclonal rabbit antibody (1:100 dilution, Neomarkers, RB-090-P010) was applied to the cases included in the study group. Normal breast tissue surrounding the tumor was used as positive control. Tumor cells were compared to surrounding normal breast tissue and staining intensities were graded semiquantitatively as negative (-), weak positive $(+)$, moderate positive $(++)$, and strongly positive $(+++)$. Staining patterns were evaluated as cytoplasmic and membranous (5). The statistical significance of the results was calculated. Statistical analysis was performed with the Chi-square test using the SPSS-10.0 package software.

\section{RESULTS}

Out of a total of 80 cases included in assessment, 52 cases (65.00\%) were IDC and 28 cases (35.00\%) were DCIS . All cases were female and the mean age was determined as 51.50 (27-81) years. The mean age was 50.63 (27-81) in IDC cases and 53.32 (32-81) in DCIS cases. Strong membranous staining was observed in immunohistochemical staining with $\beta$-catenin in normal breast tissues, especially in the ductus and lobules, luminal epithelium and basolateral surfaces. $(+++)$ staining was detected in 7 IDC cases $(13.47 \%)$ similar to normal breast tissue while this staining pattern was not observed in other cases. $(++)$ staining was observed in sixteen cases $(30.76 \%),(+)$ staining in 24 cases (46.15\%) and no staining in 5 cases $(9.61 \%)$. As for DCIS cases; $(+++)$ staining was detected in 5 cases $(17.86 \%)$ (Figure 1), (++) staining in 7 cases $(25 \%),(+)$ staining in 13 cases $(46.43 \%)$ and no staining in 3 cases $(10.71 \%)$. No statistically significant difference was found between DCIS and IDC in terms of $\beta$-catenin staining intensities $(p>0.05)$.

Membranous staining was determined in 18 IDC cases (34.61\%) (Figure 2) whereas cytoplasmic staining was observed in 29 IDC cases (55.78\%). Membranous staining was detected in 14 DCIS cases (50\%) and cytoplasmic staining in 11 DCIS cases (39.29\%) (Table I). No significant difference was determined between DCIS and IDC in terms of staining pattern in the statistical analysis $(\mathrm{p}>0.05)$.

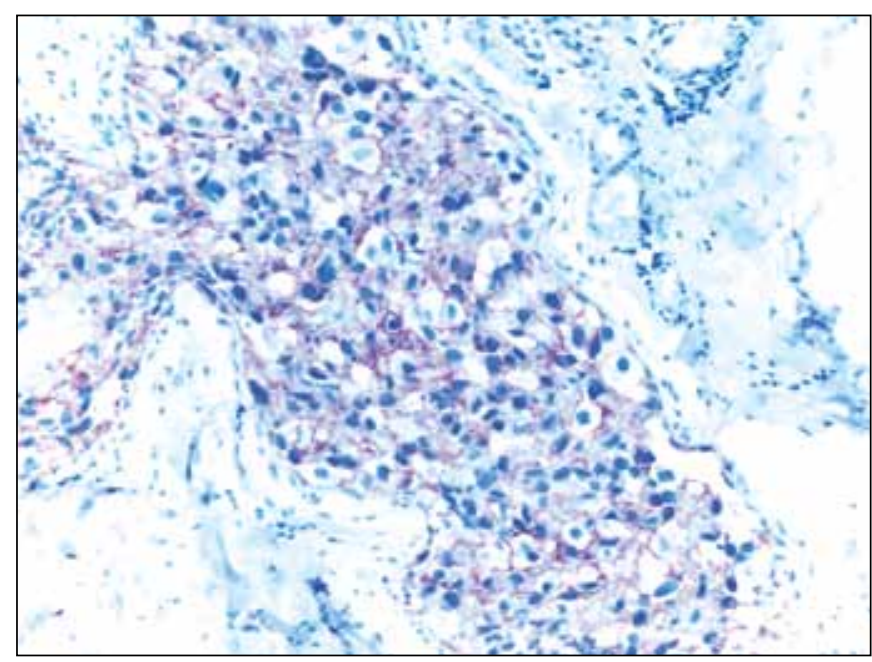

Figure 1: $(+++)$ staining with $\beta$-catenin in ductal carcinoma in situ $(\beta$-catenin, $\mathrm{x} 40)$.

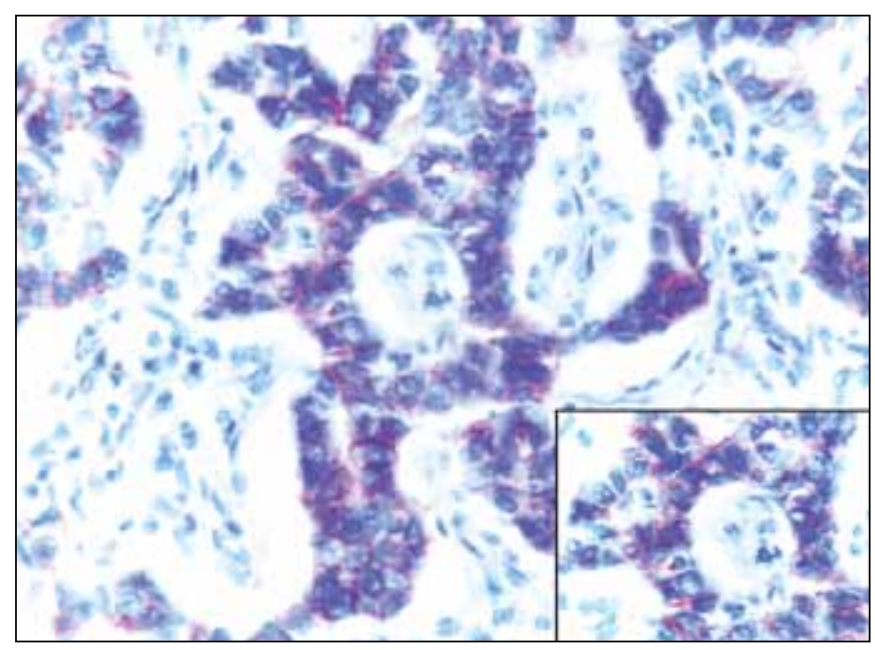

Figure 2: Membranous staining with $\beta$-catenin in infiltrating ductal carcinoma $(\beta$-catenin, $x 400)$. 
Table I: Intensities and patterns of $\beta$-catenin staining in infiltrating ductal carcinoma and ductal carcinoma in situ

\begin{tabular}{|l|c|c|c|c|c|c|c|}
\hline & Total (\%) & $+++(\%)$ & $++(\%)$ & $+(\%)$ & Membranous (\%) & Cytoplasmic (\%) & No staining (\%) \\
\hline $\begin{array}{l}\text { Infiltrating } \\
\text { ductal } \\
\text { carcinoma }\end{array}$ & $52(65 \%)$ & $7(8,75 \%)$ & $16(20 \%)$ & $24(30 \%)$ & $18(22.50 \%)$ & $29(36.25 \%)$ & $5(6.25 \%)$ \\
\hline $\begin{array}{l}\text { Ductal } \\
\text { carcinoma } \\
\text { in situ }\end{array}$ & $28(35 \%)$ & $5(6.25 \%)$ & $7(8.75 \%)$ & $13(16.25 \%)$ & $14(17.50 \%)$ & $11(13.75 \%)$ & $3(3.75 \%)$ \\
\hline Total & $80(100 \%)$ & $12(15 \%)$ & $23(29 \%)$ & $37(46 \%)$ & $32(40 \%)$ & $40(50 \%)$ & $8(10 \%)$ \\
\hline
\end{tabular}

\section{DISCUSSION}

Breast cancer ranks first in terms of cancer incidence in women and second in cancer-related deaths after lung cancer in epidemiological studies (6). Hyperplasia of the ductus and lobules is thought to be one of the most important risk factor for development of invasive breast carcinomas. The risk for development of invasive carcinoma increases with the severity of epithelial atypia (7).

Cancer progression is a spectrum starting from normal tissue and including hyperplasia, carcinoma in situ, invasive carcinoma and metastatic carcinoma. Cancer transition from the non-invasive to the invasive phase is the most important stage in progression (8). Cell-cell and cell-matrix interactions play a role in every stage of metastasis. Adhesion molecules enable these interactions (9). Essentially, changes should occur in cell-cell adhesions mediated by the cadherin family for a cancer cell to break free from the primary tumor. Interaction with catenins is essential for adhesive functions of E-cadherin which is a conventional cadherin type involved in $\mathrm{Ca}^{+2}$ mediated cellcell adhesion in epithelial cells and this interaction largely depends on $\beta$-catenin expression and function (5).

In addition to its adhesion function, $\beta$-catenin also interacts with tumor suppressor genes like APC and is involved in signal transduction pathways. Pathways containing $\beta$-catenin have been determined to play a major role in many neoplasia in recent studies.

Many studies regarding the expression of adhesion molecules in breast carcinomas have been conducted to date (10). There are studies showing a decrease in the level of many adhesion molecules including integrin and E-cadherin in breast cancer (10). $\beta$-catenin expression was demonstrated to be decreased or completely lost in cultured human breast cancer cell lines in studies $(5,11)$. This reduction may be associated with malignant transformation. Abnormal $\beta$-catenin expression was more frequently observed in invasive lobular carcinoma compared to infiltrating ductal carcinoma, and there is a complete loss of $\beta$-catenin immunoreactivity in some lobular carcinoma cases (5).

Jönsson et al. have revealed that $\beta$-catenin signals also play a role in human breast cancers by showing increased levels of cytosolic $\beta$-catenin in $13 \%$ of primary breast tumors (4).

Various IDC staining patterns and intensities have been found in different series $(5,11,12)$. On the other hand, Hashizume et al. have determined that E-cadherin, $\beta$-catenin and $\alpha$-catenin were maintained in all cases of DCIS and $70 \%$ of IDC cases and consequently reported that these proteins do not play a primary role in cancer invasion (13). They have assumed that the decrease in these proteins occur as a secondary event after main signals causing invasion such as protease production (13). Our findings suggest that $\beta$-catenin has a role in the development of breast cancer.

$\beta$-catenin expression pattern is important. Normal $\beta$-catenin expression is membranous. $\beta$-catenin shows a strong membranous staining in breast epithelium cells (2). Abnormally high amounts of $\beta$-catenin in the cytoplasm rather than within intracellular boundaries shows that the protein has acquired oncogenic potential.

Wong et al. found a high rate of cytoplasmic staining in breast tumor cells but failed to find nuclear staining in breast tumors in comparison with colon tumors (14). Studies have shown that Wnt-1 and APC genes that are positive and negative regulators of $\beta$-catenin respectively, were maintained in invasive breast cancers and less frequent 
mutations of APC were found in breast cancers compared to colon cancers (4). This also explains why there is no nuclear staining detected in breast cancers (15). Nuclear staining was detected in none of the cases in this study and this is consistent with the literature.

The membranous staining pattern was lost in the majority of IDC and DCIS cases in our study and our findings were consistent with literature $(5,16)$. The increased levels of cytoplasmic $\beta$-catenin suggest that this may be one of the steps influential in the development of IDC.

Detection of similar changes in $\beta$-catenin expression in IDC and DCIS suggests that $\beta$-catenin does not have a primary contribution to invasion.

In conclusion, the lack of a statistically significant difference between DCIS and IDC in terms of $\beta$-catenin expression in our study shows that any change in $\beta$-catenin expression develops in early carcinogenesis. However, more comprehensive studies should be performed in order to demonstrate at what stage the change in $\beta$-catenin expression occurs.

\section{REFERENCES}

1. Hülsken J, Birchmeier W, Behrens J: E-cadherin and APC compete for the interaction with b-catenin and the cytoskeleton. J Cell Biol 1994,127:2061-2069

2. Bukholm IK, Nesland JM, Karesen R, Jacopsen U, BorresenDale AL: E-cadherin and a-, b-, and g-catenin protein expression in relation to metastasis in human breast carcinoma. J Pathol 1998, 185:262-266

3. Takatama T, Shiozaki H, Shibamoto S, Oka H, Kimura Y, Tamura S, Inoue M, Monden T, Ito F, Monden M: Beta-Catenin expression in human cancers. Am J Pathol 1996, 148:39-46

4. Jönsson M, Borg A, Nilbert M, Andersson T: Involvement of adenomatous poliposis coli (APC)/ $\beta$-catenin signalling in human breast cancer. Eur J Cancer 2000, 36:242-248

5. Karayiannakis AJ, Nakopoulou L, Gakiopoulou H, Keramopoulos A, Davaris P, Pignatelli M: Expression patterns of b-catenin in in situ and invaziv breast cancer. Eur J Surg Oncol 2001, 27:31-36
6. Cotran RS, Kumar V, Collins T: Neoplasia. In Cotran RS, Kumar V, Collins T. (Eds): Pathologic Basis of the Diasease. 6th Ed., Philedelphia, W. B. Saunders Company, 1999, 260-328

7. Gültekin SE, Tuzlah P, İğdem AA, Şahan E, Tetikkurt S, Erdoğan $N$ : Memenin intraduktal hiperplazileri (IDH), atipik intraduktal hiperplazileri (AİDH) ve in situ duktal karsinomlarının (DCIS) ayırıcı tanısında LMW-CK ve HMW-CK (CK-Beta E12) kullanımının önemi. Turk Patoloji Derg 2003, 19:7-10

8. Debruyne P, Vermeulen S, Mareel M: The role of the E-cadherin/ catenin complex in gastrointestinal cancer. Acta Gastroenterol Belg 1999, 62:393-402

9. Gillett CE, Miles DW, Ryder K, Skilton D, Liebman RD, Springall RJ, Barnes DM, Hanby AM: Retention of the expression of E-cadherin and catenins is associated with shorter survival in grade III ductal carcinoma of the breast. J Pathol 2001, 193:433441

10. Gonzalez MA, Pinder SE, Wencyk PM, Bell JA, Elston CW, Nicholson RI, Robertson JF, Blamey RW, Ellis IO: An immunohistochemical examination of the expression of E-cadherin, alpha - and beta/gamma-catenins, and alpha2 - and betal-integrins in invasive breast cancer. J Pathol 1999, 187: 523-529

11. Nakopoulou L, Gakiopoulou-Givalou H, Karayiannakis AJ, Giannopoulou I, Keramopoulos A, Davaris P, Pignatelli M: Abnormal alpha-catenin expression in invasive breast cancer correlates with poor patient survival. Histopathology 2002, 40: 536-546

12. Zschiesche W, Schonborn I, Behrens J, Herrenknecht K, Hartveit F, Lilleng $P$, Birchmeier W: Expression of E-cadherin and catenins in invasive mammary carcinomas. Anticancer Res 1997, 17:561-567

13. Hashizume R, Koizumi H, Ihara A, Ohta T, Uchikoshi T: Expression of beta-catenin in normal breast tissue and breast carcinoma: a comparative study with epithelial cadherin and alpha-catenin. Histopathology 1996, 29: 139-146

14. Wong SC, Lo SF, Lee KC, Yam JW, Chan JK, Wendy Hsiao WL: Expression of frizzled- related protein and Wnt-signaling molecules in invazive human breast tumors. J Pathol 2002, 196:145-153

15. Roh H, Green DW, Boswell CB, Pippin JA, Drebin JA: Supression of b-catenin inhibits the neoplastic growth of APC- mutant colon cancer cells. Cancer Res 2001, 61:6563-6568

16. Bukholm IR, Bukholm G, Nesland JM: Coexpression of cyclin A and b-catenin and survival in breast cancer patients. Int J Cancer 2001, 94:148-149 